\title{
先史時代・歴史時代の地殼変動
}

\author{
井 関 弘太 郎 ${ }^{1}$
}

\section{Grustal Movements in the Pre-historic and Historic Times}

\author{
Hirotaro IsEKI 1 )
}

\begin{abstract}
Since the middle Jomonian cultural age (about 4,500y. B.P.) when sea level in the Recent transgression attained the highest level, the tectonic patterns and the rates of the crustal movements in several areas in Japan are demonstrated to continue to the present time.
\end{abstract}

\section{1. 縄文海進高頂期の海面と地殻変動}

ここでいう先史時代とは，繩文時代以降㴗ぼ 3 世紀に 終る弥生式時代をで限定し，いわゆる pre-Jōmon 以 前の時期を含めないこととする.

繩交時代とくにその早期中葉から前・中期にかけて は, ヨーロッパの Flandrian 海進期（バルト海の Litorina 海進)に相当する繩文海進の時期にあたるため, eustatic な海面变化の影響が強くあらわれ，地殼变動索 示す地形的証拠を eustatic change 分ら分離して求め ることが容易でない時代であった。

繩文時代の汀線変化から eustatic change の影響を除 去するための一つの課題は, 繩交海進高頂期における海 面の絶対高度を明確にすることであるが，わが国では杉 村・成瀬（1954）が東京湾沿岸で, 関東地震の際の地盤 变動の不動点に扮ける沖積世の最高汀線高度をそ机に仮 定したものを除いては，この問題を正面から検討した研 究はないとい光る・なお, この研究では繩文海進高頂期 の海面は，現海面より $6 \mathrm{~m}$ 高位にあったと推定してい る.

これとは别に，阪口（1963）はわが国の各地におい て, 旧 beach ridge の高さから高頂期の 汀線高度を求 めているが，先の結果法珻面より $4 \mathrm{~m}$ 高位にあった と結論している. この添か, 考古学遺跡からみた和島ら (1964 - 1965) の成果，㘯るいは長谷川（1966）による 化石珪藻からみた旧海面高度の研究などがあるが，これ らも現海面に比較して, 高頂期の海面功数 $\mathrm{m}$ 高位にあっ たことを認めている・しかしをれらの研究方法では必ず しも地款变動の影響を完全に除去しているとはいえない が，広範囲汇わたる高頂期海面高の共通成果からみて,阪 口が指摘するように，高頂期の海面が $+4 \mathrm{~m}$ 内外にあ
ったとして大過ないように思われる。もっとも，メキシ コ湾沿岸をはじ如アメリカの海岸を広く調査した F.P. Shepard (1955 その他) は, 沖積世に海面が現在以上に 高まったととがないとの結論に達しており，また P. Woldstedt (1958) も，北海沿岸で同じような結論をだ している.このことからみても, 日本においてこそ広範 囲にわたる地形的共通性が認的られても，それが果して 全世界的現象潽遍できるか否か泩, なお今後の問題と して残される.したがって，ここでは一㐫の作業仮説と して阪口の推定した 現海面 $+4 \mathrm{~m}$ を高頂期の海面とし て报い，それとの相対的関係で繩交時代以降の地殼变動 を考察することにする。

関東地方は，第四紀地形敊よび考古学研究がわが国で も最も高密度に行なわれてきた地域である。それゆ光， まずこの地域に例をとって先史洔代以降に新ける地豰变 動の規模と，そのような運動の第四紀地殼変動史におけ る位置づけを考えてみたい．

関東構造盆地の南縁をな房総半島南部では, 中野尊 正（1952）の調查で明らかになったように，繩交前期以 降に $25 \mathrm{~m}$ 以上の地盤上昇の亦ったことが，加茂遺跡 (千葉県安房郡・繩交前期諸磯期) の独木舟 ${ }^{14} \mathrm{C}$ 值 $5290 \pm 140$ B.P.）を包含する海成粘土層とそれを被う磷 層からなる海岸段丘の高さによって示されている。これ に対比される段丘面（沼さんご層の頂面高度）は，東京 湾沿岸の場合, 北们向かって低下し, 千葉市付近では 5 $\mathrm{m}$ 内外になるが，このような海岸段丘面の高度分布と関 東地震による地盤变動量との間化高い相関関係のあるこ とは，上述の杉村・成瀬の研究によって明らかにされて いる。すなわち，段丘面高度=旧汀線高度（y） と関東 地震時の地盤変動量 $(\mathrm{x})$ との間の関係式は, $\mathrm{y}=6+11 \mathrm{x}$ となっている.

1) 名古屋大学交学部, Faculty of Literature, Nagoya University, Nagoya 
このような現象は, 東京湾北縁部より北側の関東地震 時の沈降部においても認められる。最近，阪口（1968） によって報告されたように, 関東構造盆地盆央部の栗橋 付近に括いて繩交海進時の海成層の上面が，埼玉県大利 根村北下新井で海抜 $1 \mathrm{~m}$ ，また幸手市下野・下高野でも 海面下 $0.7 \mathrm{~m}$ と，阪口が推定した高頂期海面より 3〜 $4.7 \mathrm{~m}$, さらに杉村·成瀬の推定值より 5 6.7m 低位 にあることがわかった。最近，これらの地点に近い江川 貝塚（茨城県猿島郡五霞村 · 繩交前期黑浜式 ·諸磯式 期）の地質 ·古微生物調查の結果, 高頂期海水準が海抜 $0.5 \mathrm{~m}$ 内外にあったことが和島ら（1968）によって報告 されている.したがって，杉村・成瀬らの求めた関係式 にあてはめれば，栗橋方面は関東地震に際して地盤が $0.45 \sim 0.61 \mathrm{~m}$ 沈降したことになるが，その值は宮部 (1952) が整理した水準再測結果（約 $-100 \mathrm{~cm}$ ）からみ てやや小さいと法いえ，その傾向に大きな差違のないこ とが認められる・換言すれば, 繩文時代以降における地 殻变動の傾向が，第四紀地殼变動の大きな傾向と矛盾し ないばかりでなく，過去数十年間の水準点標高の变動状 況ともほぼ同傾向にあることを示す一事例ということが できる.

\section{2. 海面高頂期以降の海面変化と地殻变動}

繩交海進の高頂期は, 関東地方における貝塚分布の状 況からみて, 繩文前期黑浜式期といわれてきたが，しか し上述した阪口の報告によれば，海岸線の最浸入期と海 面の高頂期とを区別して検討すると, 後者は海成層直上 の泥炭の年代值 $\left({ }^{14} \mathrm{C}\right.$ 年代值 $\cdot 4120 \pm 100$ B.P. ·東京大 学 ${ }^{14} \mathrm{C}$ 編年委員会） からみて, 関東地方でも繩文中期 の時期にあたることが明らかになった。

このことは isostatic な地盤上昇のなかったデンマー ク以西のヨーロッパにおいて, Flandrian 海進 (Atlantic 海進）の高頂期が B.C. 2000 年ごろとする報告の多い ことと矛盾しない。また国内的にみても, 濃尾平野など 繩交中期の貝塚（同平野では庭田・長久寺貝塚）が最奥 部の貝塚になっているのをはじめ，高頂期の時期につい て大阪平野では $4,260 \pm 90$, 能登半島でも $4,500 \pm 90$ B.P.などの年代がえられている（藤井，1967）.

これらの事実からみて, 繩文海進の高頂期を繩交中期 とした場合，それを裏付けるかたちの先史遺跡が銚子市 の粟島台遺跡である. 同遺跡は, 砂質凝灰岩からなる台 地を開析する前田川の沖積段丘にある遺跡であるが，沖 積段丘（海抜 $7 \mathrm{~m}$ ) を構成する地層中には，繩文早期 （浮島期）から繩文中期（加曾利 $\mathrm{E}$ 式期）までの土器片
が層状に包含されており,この間, 堆積がほぼ連続的に 進行したことを示している，乙かるに加會利 $\mathrm{E}$ 式期（約 4500 B.P.) 以後, 急激な浸食の復活が進み, 少なくと も深さ $3.5 \mathrm{~m}$ 以上に及ぶ谷中谷が形成された．この谷 中谷は, 現在は厚さ $3.5 \mathrm{~m}$ 以上に及占泥炭層によって 充填されているが，その形成に際しては，気候変化にと もなう漸進的な eustatic change（海面低下）によるよ りも，地震などにともなら急速な地盤上昇（1 回きりと は限らなからう）による浸食の復活に主因があったよう な形状を呈している。

しかしこのことは，繩交海進高頂期以後に eustaticな 海面低下のあったことを否定するものではないむし ろ，海面上昇の停止ないしは海面の eustatic な低下に よって，地殼变動とくに地盤上昇の痕跡が，地形・地質 に顕著に残される状態になったことを示している．この ように繩文中期以後, 地盤変動の痕跡が海面上昇によっ て消去されることがなくなると，いきおい地殼運動の地 域差の影響がそのまま地域的特徵として現われるように なった。

一つの地域的特徵として顕著なものは，東海地方の臨 海平野における繩文後晚期の海面の相対的低下と, 繩交 晚期ないし弥生式期にかけての相対的再上昇である.

井関（1950）は豊川沖積平野において試錐調査を行な った結果, 現海面下 $3.4 \mathrm{~m}$ 以深に達する埋積谷のあるこ とを明らかにした。この埋積谷は, 粗砂・中砂からなる 海岸平野面上に延びた旧豊川の延長川であるが，そのよ うな海岸平野および延長川の形成は，いうまでもなくこ の方面における海面低下（相対的か絶対的かは不明）を 示すものであり，その時期は同埋積谷の沿岸に繩交晚期 の貝塚（大蚊里·五貫森遺跡）や弥生式中期の貝塚（瓜 郷遺跡）が立地していることからみて，繩交晚期以前で あったことがわかる。

また加藤・井関 (1962) は，西遠州平野においてやは り海岸平野面に延長した小河川が，現海面下 $3 \mathrm{~m}$ 以深に 及ぶ埋積谷を形成していたことを試錐調査で明らかにし た.この埋積谷の形成も，その上に弥生式後期遺跡（大 場遺跡）がのることからみて，弥生式期以前であること は確実である。このほか井関はこれに類似した地形を濃 尾平野南部（名古屋市西志賀遺跡付近）においても確認 している.

上述の采島台遺跡を含めた東海地方諸平野についての 調査の結果，本来ならば低潮面以深になることがほとえ どない小河川の河床が，それ以下になっている埋没延長 川の地形などからみて, 繩文中期以降海面は相対的に低 
下し，現海面より少なくとも $1 \sim 2 \mathrm{~m}$ 以上低くなったこ とが明らかになった。しかしそれらの延長川の浅谷は繩 交晚期ごろには沈水ないしは湿地化し，その縁辺に噦水 性ないしは主淡水性貝塚の形成されたことが，豊川平野 の大蚊里・五貫森遺跡などにその例をみることができ る・したがって，繩文中期以後に一旦低下した海面は， 繩交晚期ごるには再び上昇へ向かったと解することがで きる.

このような海面变化の形態が，東海地方のかなり広範 团にわたる平野に共通してみられる現象であることか ら，筆者もこれが eustatic な海面変化であるとの考方方 をむったこともあるが，しかし調査範囲をさらに広げる にしたがって, 海面変化の過程が必ずしもこれと同じ経 過をたどるものばかりでないことがわかってきた．その 最も顕著学事例は熊本県八代平野の場合であり，ここで は平野最奥部（山ろく部）に繩文後期の遺跡が分布し， 繩交後期に海進の頂点のあったことを示している・また 小野忠㜯（1963）も山口県宇部市付近の海岸では, 繩交 後期初頭に 小海進 (陸地の沈降) があった後海退に転 じ, 繩文後期中葉から弥生式時代をへて古墳時代の中期 ごろまで相対的な海退期のつづいたことを報告してい る.このような東海地方から離れた地域ばかりでなく, 東海地方のなかでも上述の事例とは異なる海面変化の経 過をたどった地域がみられる. 西三河平野などはその好 例である. 西三河平野の境川水系では, 繩交後期中葉の 上カス貝塚 (刚谷市一ッ木・上カス：ハイガイを主とし てカキ・アカニシ・シジ々等を混在), また矢作川水系 では, 繩交晚期中葉の桜井貝塚（安城市桜井町堀内：八 マグリ・カキ・アサリ・アカニシ等）が最奥部の墭水性 貝塚になっている。

このように繩交中期以後における各地の汀線変化に多 様性のあることが認められるが，しかしそのことが繩文 中期の海面高頂期以後, 海面が低下したとするこれまで の考光方を否定するものではない，先に述べたように， むしろえうした海面の低下傾向が前提にあったからこ そ, その後の各地に柇ける地殼変動が敏感に地形・地質 に反映するようになったものと推測される.

東海地方の臨海部には, さまざまな地殻変動が歴史時 代以後においても発生している。例えば，多田（1943） は遠州灘沿岸横須賀付近において, 宝永 4 年 (1707) の 大地震に際して 地盤が隆起し, それ以前の入江が干潟 になったことを，その前後の古地図・文献から明らかに している。こうした現象は, 関東地震炕際しての東京 湾・相模湾沿岸の $1 \mathrm{~m}$ 以上に及ぶ変動, あるいは三河地
震（1945）に際しての愛知県幡豆海岸の隆起など，明治 期以降においても各地にみられ, 東海地方臨海部の地盤 がかなり不安定な状態にあり，乙かもそれらがブロック 的な地域的現象として活動している場合の多いことがう かがわれる. 先史時代に㧍けるこうした現象が当時の汀 線移動の地域差に敏感に反映するようになったのは，上 述のように, 海面上昇が一段落ないしは下降をしたこと に重要な条件があったと考元られるのである。

\section{3. 弥生式時代以降の地殼変動と第四紀地殻変動}

東海地方の諸平野に打ける地殼運動が, それぞれの地 域を一つの単位としてブロック状に進行しているが, 各 単位地域における運動の傾向は, 少なくとも先実時代 · 歴史時代を通じてかなり共通した運動ないしは運動形態 を示していることが認められる。

濃尾平野では 1885 年以降, 数次にわたる水準点の改 測が行なわれているが，とくに 1891 年の濃尾地震をは さむ 1885〜1895 年の間における変動量が示すように, 浱尾平野は大きくみて, 岐阜・一宮・名古屋を結ぶ東海 道本線付近を軸として東高西低の傾動を行なっているこ とがうかがわれる（正確には, 断層線としての同不動軸 付近を境にして 2 つブロック運動一東部の隆起区と西 部の沈降区一に細分される)，このような地殼変動の形 態が, 濃尾平野の第四紀以降における一般的傾向である ことは，段丘地形の分布や第四紀諸層の傾斜状況などに 認められるが，先史遺跡あるいは歴史時代の遺構分布に もそうした一連の運動形態をとらえることができるので ある。

濃尾平野における弥生式時代の貝塚および最も海寄り にある遺跡（遺物包含地）の状況を, 平野の東部から西 部に向かって求めると次のようになる.

(1) 西志賀貝塚（名古屋市北区貝田町）：弥生式前. 中期の貝塚で，初期はカキを主とするが，中期になって ハマグリを主とするようになる. 現在の地表標高は海抜 4.5〜 5m であり，包含層は海拡 3〜 $4 \mathrm{~m}$ にある.

(2) 貝殼山貝塚（愛知県清洲町朝日）：西志賀遗跡の 北西約 $5 \mathrm{~km}$ にあり, 上述した濃尾平野傾動運動の不動 軸付近にある. 弥生式前・中期の貝塚で，マガキが多 く，ハマグリがこれに次ぎ，他にシジミ・アカニシ・オ オノガイなどからなる主緘貝塚で, 地表標高は海抜約 3 $\mathrm{m}$ ，包含層注同じく 2 2.5m.

(3) 阿弥陀寺包含地 (愛知県甚目寺町新居屋) : 西志 賀遺跡の西 $7.5 \mathrm{~km}$. 濃尾平野沖積地における最南部の 弥生式遺跡, 中. 後期. 地表の海拔標高 $1.5 \mathrm{~m}$, 包含層 
将同じく $0.9 \sim 0.3 \mathrm{~m}$.

(4) 四郷遺跡（岐阜県輪之内町四郷）：西志賀遺跡の 西北西 $25.8 \mathrm{~km}$ にあり, 輪中地域唯一の先史遺跡で, 弥生式後期汇属する. 地表標高は海抜 $1 \mathrm{~m}$, 包含層は海 抜 $0 \mathrm{~m}$ なし $-1.0 \mathrm{~m}$.

以上の点からみて, 濃尾平野東部の西志賀遺跡と西部 の四鄉遺跡との間には，包含層に 3〜 5m の標高差のあ ることがわかるが，とくに前者注海岸に近接して立地し たであろう貝塚であるのに対して, 後者は必ずしも海岸 にあった遺跡でないことを考慮すれば，こうした標高差 は，大部分が遺跡形成以後における地盤変動によって生 ビたものと考えて大過ないように思われる。

上述のような数值から, 西志賀遺跡と四鄉遺跡との間 の傾斜量注 $0.19 / 1,000$ (以上?) となり, 貝殼山遺跡 の包含層標高 $2 \sim 2.5 \mathrm{~m}$ を不動として計算すれば, 四郷 遺跡付近における遺跡形成後の沈下量は, $3 \sim 3.5 \mathrm{~m}$ (以 上?）となり，弥生式時代から現在までを $2 \times 10^{3}$ 年と すれば，年間沈下量は $1.5 \sim 1.75 \mathrm{~mm} /$ 年 となる.この 值は嘉藤・桑原ら (1967) が求めた八事面および熱田面 形成以後にお污る年間沈下量（とくに熱田面の沈下速 度）に極めて近似していることが注目される。

表 1. 地形面および先史遺跡間の傾動運動 による沈下量

\begin{tabular}{|c|c|c|c|c|}
\hline \multirow{2}{*}{$\begin{array}{l}\text { 計算に用 } \\
\text { いた地形 } \\
\text { 面と先史 } \\
\text { 遺跡 }\end{array}$} & \multirow{2}{*}{$\begin{array}{l}\text { 面・遺跡の } \\
\text { 形成された } \\
\text { 年代 }\end{array}$} & \multirow{2}{*}{$\begin{array}{l}\text { 面·遺跡 } \\
\text { 間の傾斜 } \\
\text { 量 }\end{array}$} & \multicolumn{2}{|c|}{$\begin{array}{l}\text { 弥富付近の面形成 } \\
\text { 後および四䐚遺跡 } \\
\text { 形成後の }\end{array}$} \\
\hline & & & 沈下量 & 年間沈下量 \\
\hline $\begin{array}{l}\text { 熱田面 } \\
\text { 八事面 }\end{array}$ & $\begin{array}{c}3.5 \times 10^{4} \mathrm{BP} \\
3 \times 10^{5} \\
\mathrm{BP}(?)\end{array}$ & $\left|\begin{array}{r}2.5 / 1,000 \\
12.5 / 1,000\end{array}\right|$ & $\begin{array}{r}60 \mathrm{~m} \\
300 \mathrm{~m}\end{array}$ & $\begin{array}{r}1.7 \mathrm{~mm} / \text { 年 } \\
1 \mathrm{~mm} / \text { 年 }\end{array}$ \\
\hline $\begin{array}{l}\text { 西志賀 } \\
\text { 四鄉生 } \\
\text { 式遺跡 }\end{array}$ & $2 \times 10^{3}$ & $0.19 / 1,000$ & $3 \sim 3.5 \mathrm{~m}$ & $\begin{array}{c}1.5 \sim 1.75 \\
\mathrm{~mm} / \text { 年 }\end{array}$ \\
\hline
\end{tabular}

（注）：熱田面・八事面の数值は，横尾義貫・嘉藤良 次郎・桑原徹の数值（1967）を用いる.

なお，このような沉下速度は, 愛知県十四山村鳥ヶ地 付近 (1 等水準点標石番号 1473 号) に打汀る, 大規模 地震のない期間の年間沈下量をやや上迴る值を示してお り, より正確には約 200 年間に 1 回の割合で濃尾地震に 際しての沈降量（同水準点では $0.1010 \mathrm{~m}$ ) 程度の沈降 がそれに加わった值であるといえる。

愛知県海部郡十四山村鳥ヶ地（標石番号 1473 号）に お汀る年間沈下量

$$
\text { 期間染下量 }
$$

(1) $1888 〜 1955$ 年の間 (濃尾地震・東南海 $9.2 \mathrm{~mm}$ 地震による沈降量を含む)

(2) $1888 \sim 1931$ 年の間（濃尾地震の沈降量 3.4 を含む)

(3) $1895 〜 1931$ 年の間(大規模な地震なし) 1.2

\section{4. 考察}

(1) 関東構造盆地というような地形単位のなかにおい ては, 先史時代（繩文時代）以降の地殼変動の傾向は, 水準点標高の変動にみられる最近のそれと大差劣い状態 にあることが認められた。

(2) 繩交海進の高頂期（繩文中期）以降，海面の低下 ないしは停滞によって，地域的な地殼変動の影響が敏感 に地形・地質にあらわれるようになった。したがって旧 汀線付近の考古学的遺跡の分布からみた海面高頂期以後 の汀線変化の過程・時期は地域的にかなりまちまちにな っている.

(3) しかし地形区ごとに弥生式時代以降の地殼変動の 状況をみると，少なくとも濃尾平野に括ける事例では， 最近における地殼变動の速度と等速度で，同じ傾向の運 動の進えでいることが明らかになった。また，そのよう な運動の傾向・速度は, 同平野の場合, 洪積世後期以降 ほぼ同じ状態にあることがわかった。

これらの結果, 多くの地域では, 人為的な圧密収縮の 加速による影響のない限り, 最近の水準点標高の変化に みられる地殼変動の傾向㧍よび平均速度は，少なくとも 先史時代（繩交時代）にまで延長させて考えて差しつか えないことが明らかになった。

謝辞：この論文の作成にあたって，多くの凟料を賜っ た小野忠熈氏に深く感謝致します。

\section{引用交献}

藤井昭二（1967） “沖積層” と炎の絶体年代一後水期の 時代区分の試み一。第四紀研究，6，192～199.（濃尾 平野 <刈谷〉については $5,470 \pm 450 \mathrm{y}$. B.P. の值を あげている.)

長谷川康雄 (1966) 関東平野の前期繩交時代に括沙る沖 積土の微古生物学的研究一化石珪藻についてそのI.

資源研燢報，67，73〜82.

井関弘太郎（1952）鉆子市南小川町栗島台繩文式遺跡付 近の地史. 上代交化，22，9～13.

（1950）初期米作集落の立地環境一愛知県瓜郷遺跡 の場合. 資源研葆報, 16, 6 10.

- - 加藤芳朗 (1962) 自然地形. 蜆塚遺跡. 総括編, 浜松市教育委員会, 4 13.

Miyabe, N. (1952) Vertical earth movements in Japan as deduced from the results of rerunning the precise levels. Bull. Earthq. Res. Inst., 30, 2, 127 162. 名古屋大学地盤变動研究グループ（1967）伊勢湾北部地 
域地盤沈下調査研究報告書 $77 \sim 102$.

中野尊正 (1952) 日本海岸低地地形に関する若干の問 題. 駿台史学, 2, 59 72.

小野忠熙 (1963) 本州西端地方に和ける海岸砂丘の形成 期の研究. 地理評，36，(7)，391〜411.

阪口 豊 (1963) 日本の後水期海面変動に対する疑問一 繩交文化の絶対編年に寄せて一。第四紀研究 2, (6), $211 \sim 219$.

阪口豊（1968）沖積世に打関東平野中央部の陸化 期の年代. 第四紀研究，7，(2)，57〜 58.

Shepard, F. P. \& Moore, D. G. (1955) Central Texas coast sedimentation : Characteristics of sedimentary environment, recent history, and diagenesis. Bull. Amer. Assoc. Petrol. Geol. 39, (8), $1463 \sim 1593$.

Sugimura, A. and Naruse, Y. (1954) Changes in sea level, seismic upheavals, and coastal tarraces in the southern Kantō region, Japan ( I ). Japan. J. Geol. \& Geogr., 24, 101 113.

多田文男 (1943) 遠州灘沿岸横須賀付近の海岸地形一歴 史時代に隆起せる干渴の一例一. 地理評, 19, (12), $1 \sim 7$.

和島誠一ほか (1964) 北九州における後氷期の海進海退 について．資源研受報，63，64～72.

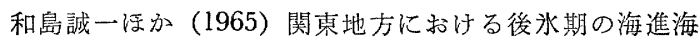
退について. 関東地方に拧活る自然環境の变遷に関す る総合的研究, 資源研, 5 10.

和島誠一 - 松井 健 - 長谷川康雄 - 岡本 勇 - 塚田光 田中義昭 - 中村嘉男 - 小宮恒雄 - 黑部隆 - 高橋健一 佐藤 孜 (1968) 関東平野における繩文海進の最高海 水準について，資源研獣報，70，108～129.

Woldstedt, P. (1958) Das Eiszeitalter. Bd, II , 438 S., Ferdinand Enke. 